\title{
POJECCIE I POSTACIE UTWORU NAUKOWEGO W ŚWIETLE PRAWA AUTORSKIEGO
}

\section{PRZEPISY PRAWA}

W przepisach ustawy o prawie autorskim i prawach pokrewnych ${ }^{1}$ nie zdefiniowano utworu naukowego - poprzestano na wymienieniu go w art. 1 ust. 2 pkt1 i poświęcono mu art. 14, a także odwołano się do tego pojęcia w art. 29 pr.aut. (cytowanie), jak również w sferze regulacji praw pokrewnych (art. $99^{2}$ pr.aut. - prawo do wydania krytycznego lub naukowego). Ponadto również w innych przepisach prawa polskiego brak definicji utworu naukowego. Jedynie w komunikacie Ministra Nauki i Szkolnictwa Wyższego z 29 maja 2013 r. w sprawie kryteriów i trybu oceny czasopism naukowych (w przypisie do pkt 10 lit. e) stwierdza się, że przez artykuł naukowy należy rozumieć „artykuł prezentujący wyniki oryginalnych badań o charakterze empirycznym, teoretycznym, technicznym lub analitycznym zawierający tytuł publikacji, nazwiska i imiona autorów wraz z ich afiliacją i przedstawiający obecny stan wiedzy, metodykę badań, przebieg procesu badawczego, jego wyniki oraz wnioski, z przytoczeniem cytowanej literatury (bibliografię)"2.

Wśród przepisów prawa międzynarodowego na uwagę zasługuje treść art. 2 ust. 1 Aktu paryskiego Konwencji berneńskiej, który stanowi, że określenie „dzieła literackie i artystyczne” obejmuje wszystkie dzieła literackie, naukowe i artystyczne, bez względu na sposób lub formę ich wyrażenia, takie jak książki, broszury i inne pisma; odczyty, przemówienia, kazania i inne dzieła tego rodzaju; dzieła dramatyczne lub dramatyczno-muzyczne; dzieła choreograficzne i pantomimy; dzieła muzyczne ze słowami lub bez słów; dzieła filmowe oraz zrównane z nimi dzieła wyrażone w podobny sposób jak film; dzieła fotograficzne oraz zrównane z nimi dzieła wyrażane w podobny sposób jak fotografia; dzieła sztuki użytkowej, ilustracje, mapy geograficzne, plany, szkice i dzieła plastyczne dotyczace geografii, topografii, architektury lub innych nauk ${ }^{3}$. Za istotny należy także uznać art. I Konwencji powszechnej, w myśl którego każ-

1 Ustawa z 4 lutego 1994 r. o prawie autorskim i prawach pokrewnych, t.jedn.: Dz. U. 2006, Nr 90, poz. 631 ze zm. (dalej jako: pr.aut.).

2 Zob.http://www.bip.nauka.gov.pl/g2/oryginal/2013_06/eb78827ca3f6638d25b5124c3ba02ee8. pdf (dostęp: 18.12.2014).

${ }^{3}$ Akt paryski Konwencji berneńskiej o ochronie dzieł literackich i artystycznych, sporządzony w Paryżu dnia 24 lipca 1971 r. (Załącznik do Dz. U. 1990, Nr 82, poz. 474). 
de umawiające się państwo zobowiązuje się przedsięwziąć wszelkie niezbędne środki w celu zapewnienia dostatecznej i skutecznej ochrony praw autorów i wszystkich innych podmiotów tych praw, dotyczacych dzieł literackich, naukowych i artystycznych, takich jak: dzieła pisane, utwory muzyczne, dramatyczne i filmowe, dzieła malarskie, graficzne i rzeźby ${ }^{4}$. Z regulacji tych wynika wniosek kluczowy dla dalszych rozważań, że podstawowe dla prawa autorskiego regulacje nie stanowią żadnych ograniczeń form wyrażania utworów naukowych, w szczególności nie ograniczają ich do form piśmienniczych.

Z przepisów prawa polskiego można jednak wyprowadzić wniosek odnośnie do obszerności płaszczyzny, na której można prowadzić rozważania na temat pojęcia utworu naukowego. W rozporządzeniu Ministra Nauki i Szkolnictwa Wyższego z 8 sierpnia $2011 \mathrm{r}$. w sprawie obszarów wiedzy, dziedzin nauki i sztuki oraz dyscyplin naukowych i artystycznych ${ }^{5}$ przedstawiono w załaczniku następujący wykaz dziedzin nauki: humanistyczne, teologiczne, społeczne, ekonomiczne, prawne, matematyczne, fizyczne, chemiczne, biologiczne, o Ziemi, techniczne, rolnicze, leśne, weterynaryjne, medyczne, farmaceutyczne, o zdrowiu, o kulturze fizycznej. Następnie w ramach powyższych dziedzin nauki wyróżniono liczne dyscypliny naukowe $e^{6}$.

Powołany wykaz obrazuje wielość dyscyplin, w których mogą manifestować swoją obecność utwory naukowe. Podkreślenia wymaga, że z uwagi na różnorodność dyscyplin nauki utwory naukowe powstające na ich potrzeby moga, a nawet powinny opierać się na kontrastowo różnych środkach wyrazu. Bezsprzecznie zatem nie tylko utwór piśmienniczy będzie mógł spełniać kryteria utworu naukowego, co może dominować w dziedzinie nauk humanistycznych, teologicznych, społecznych, ekonomicznych i prawnych. W dziedzinie nauk matematycznych, fizycznych, chemicznych, biologicznych, o Ziemi, technicznych, rolniczych, leśnych, weterynaryjnych, medycznych, farmaceutycznych, o zdrowiu i o kulturze fizycznej moga w charakterze utworów naukowych pojawiać się także utwory plastyczne, fotograficzne, architektoniczne, architektoniczno-urbanistyczne, urbanistyczne i audiowizualne. W pozostałych dziedzinach

${ }^{4}$ Powszechna konwencja o prawie autorskim zrewidowana w Paryżu dnia 24 lipca $1971 \mathrm{r}$. (Załącznik do Dz. U. 1978, Nr 8, poz. 28).

${ }^{5}$ Dz. U. Nr 179, poz. 1065.

${ }^{6}$ Archeologia, bibliologia i informatologia, etnologia, filozofia, historia, historia sztuki, językoznawstwo, kulturoznawstwo, literaturoznawstwo, nauki o rodzinie, nauki o sztuce, nauki o zarządzaniu, religioznawstwo, nauki o bezpieczeństwie, nauki o obronności, nauki o mediach, nauki o polityce, nauki o polityce publicznej, nauki o poznaniu i komunikacji społecznej, pedagogika, psychologia, socjologia, ekonomia, finanse, nauki o zarządzaniu, towaroznawstwo, nauki o administracji, prawo, prawo kanoniczne, matematyka, informatyka, astronomia, biofizyka, fizyka, geofizyka, biochemia, biotechnologia, chemia, ochrona środowiska, technologia chemiczna, biochemia, biofizyka, biologia, biotechnologia, ekologia, mikrobiologia, ochrona środowiska, geofizyka, geografia, geologia, oceanologia, architektura i urbanistyka, automatyka i robotyka, biocybernetyka i inżynieria biomedyczna, biotechnologia, budowa i eksploatacja maszyn, budownictwo, elektronika, elektrotechnika, energetyka, geodezja i kartografia, górnictwo i geologia inżynierska, informatyka, inżynieria chemiczna, inżynieria materiałowa, inżynieria produkcji, inżynieria środowiska, mechanika, metalurgia, technologia chemiczna, telekomunikacja, transport, włókiennictwo, agronomia, biotechnologia, inżynieria rolnicza, ochrona i kształtowanie środowiska, ogrodnictwo, rybactwo, technologia żywności i żywienia, zootechnika, drzewnictwo, leśnictwo, biologia medyczna, medycyna, stomatologia. Ponadto w wykazie wymieniono dyscypliny artystyczne. 
działalność naukowa może przynieść rezultat w postaci utworu muzycznego, słowno-muzycznego, scenicznego, sceniczno-muzycznego, choreograficznego, pantomimicznego, audiowizualnego, fotograficznego i plastycznego.

\section{REGULAMINY UCZELNI WYŻSZYCH}

W myśl art. 86c ustawy z 27 lipca 2005 r. - Prawo o szkolnictwie wyższym, senat (w przypadku uczelni niepublicznych organ wskazany w statucie) uchwala regulamin zarządzania prawami autorskimi i prawami pokrewnymi oraz prawami własności przemysłowej oraz zasad komercjalizacji, który określa w szczególności:

1) prawa i obowiązki uczelni, pracowników oraz studentów i doktorantów w zakresie ochrony i korzystania z praw autorskich i praw pokrewnych oraz praw własności przemysłowej,

2) zasady wynagradzania twórców,

3) zasady i procedury komercjalizacji,

4) zasady korzystania z majątku uczelni wykorzystywanego do komercjalizacji oraz świadczenia usług naukowo-badawczych ${ }^{7}$.

Można by się zatem spodziewać uwzględnienia definicji utworu naukowego w ustawowo scharakteryzowanych regulaminach, ponieważ pojęcie to można uznać za podstawowe dla wymaganej prawem regulacji. W celu zbadania istniejącego stanu faktycznego w tym względzie dokonano przeglądu regulaminów $20^{8}$ polskich uczelni wyższych ${ }^{9}$, uchwalonych przed 1 października 2014 r.

Tylko w dwóch przypadkach (Politechnika Lubelska ${ }^{10}$ i Politechnika Gdańska $^{11}$ ) zastosowano w regulaminie lakoniczną definicję utworu naukowego jako utworu zawierajaccego rezultaty pracy naukowej. Ponadto z treści regulaminów można wyprowadzić katalog utworów, które mogą być uznawane za utwory naukowe, a mianowicie: prace magisterskie, rozprawy doktorskie, rozprawy habilitacyjne, monografie, artykuły, prace twórcze oparte na oryginalnym materiale eksperymentalnym lub wnoszące nowe oryginalne wyniki badawcze, książki

\footnotetext{
${ }^{7}$ T.jedn.: Dz. U. 2012, poz. 572 ze zm.

${ }^{8}$ Należy zaznaczyć, że nie we wszystkich polskich uczelniach wyższych uchwalono regulaminy zarządzania prawami autorskimi i prawami pokrewnymi oraz prawami własności przemysłowej oraz zasad komercjalizacji.

${ }^{9}$ Uniwersytet Gdański, Uniwersytet Łódzki, Uniwersytet Jagielloński, Politechnika Lubelska, Akademia Górniczo-Hutnicza im. Stanisława Staszica w Krakowie, Uniwersytet Warszawski, Politechnika Krakowska im. Tadeusza Kościuszki, Politechnika Gdańska, Politechnika Śląska, Uniwersytet Medyczny w Białymstoku, Uniwersytet Warmiński-Mazurski w Olsztynie, Uniwersytet Śląski w Katowicach, Uniwersytet Mikołaja Kopernika w Toruniu, Uniwersytet Opolski, Uniwersytet Muzyczny Fryderyka Chopina, Zachodniopomorski Uniwersytet Technologiczny w Szczecinie, Uniwersytet Rzeszowski, Pomorski Uniwersytet Medyczny, Uniwersytet Wrocławski, Uniwersytet Artystyczny w Poznaniu.

${ }^{10}$ Regulamin ochrony i korzystania z własności intelektualnej, http://www.pollub.pl/files/4/ news/files/1705_Zarzadzenie,Nr,R-13-2011.pdf (dostęp: 18.12.2015).

${ }^{11}$ Regulamin ochrony i korzystania z własności intelektualnej, http://ctwt.pg.edu.pl/documents/10847/ae642e5b-7655-4ba3-a023-64270b7b4fa2 (dostęp: 18.12.2015).
} 
naukowe (tzn. zwarte opracowania z odwołaniem do materiałów źródłowych, dotyczące sprecyzowanego obszaru wybranej dziedziny lub dyscypliny naukowej), artykuły naukowe porządkujące określony obszar wiedzy naukowej lub cykl wyników badawczych, programy komputerowe, bazy danych, dzienniki prac badawczych, materiały dydaktyczne, podręczniki, skrypty, zeszyty, materiały e-learningowe, programy studiów, sylabusy, programy zajecć, ekspertyzy, utwór audiowizualny. W wielu uczelniach stwierdzono brak zarówno definicji utworu naukowego, jak i przykładów tego typu utworów ${ }^{12}$.

\section{KLASYFIKACJA UTWORU JAKO UTWORU NAUKOWEGO W DOKTRYNIE}

Na tle przepisów ustawy o prawie autorskim z 1926 r. ${ }^{13}$ Stefan Ritterman twierdził, że dzieła naukowe „przedstawiają w sposób jak najbardziej syntetyczny rzeczywistość, albo też zajmują się technika, metodą poznawania rzeczywistości, a wówczas obracają się w sferze abstrakcji, w sferze »czystych myśliı (teoria poznania, logika, matematyka); świat fantazji jest dla nauki przedmiotem badań chyba tylko jako fenomen psychologiczny, a zatem znowuż jako »rzeczywistość« [...]. Nauka zajmuje się poznawaniem, jest - co do treści - odtwórcza, świat fantazji jest tedy naukowej pracy obcy, bo w nim króluje indywidualna twórczość” ${ }^{14}$. W związku z tym zdaniem Rittermana „dzieło naukowe jest tylko $\mathrm{z}$ uwagi na swą formę, a nie także $\mathrm{z}$ uwagi na swą treść "dziełem" w rozumieniu ustawy autorskiej, i dlatego na gruncie t e j ustawy tylko co do formy - tak zewnętrznej, jak i wewnętrznej - ochronie prawnej podlega" 15 .

Pod rządami ustawy o prawie autorskim z 1952 r. ${ }^{16}$ Andrzej Kopff uważał, że dzieło naukowe służy przede wszystkim poznaniu czy też odkryciu pewnej obiektywnie istniejącej rzeczywistości lub praw nią rządzących ${ }^{17}$. Dzieło naukowe powstanie swe zawdzięcza zamierzeniom i czynnościom poznawczym autora, który z kolei wynik swych ustaleń stara się przekazać odbiorcom w sposób jednoznaczny, a więc niebudzący wątpliwości co do intencji wykła$\mathrm{du}^{18}$. Oryginalność utworów naukowych, a zarazem ich ciężar gatunkowy, tkwi w dowodzie, czyli w porównaniu tez z rzeczywistością obiektywna, istniejąca poza twórcą i niezależnie od jego woli. Użyte środki przedstawiające przybie-

${ }_{12}$ Politechnika Krakowska im. Tadeusza Kościuszki, Uniwersytet Mikołaja Kopernika w Toruniu, Uniwersytet Opolski, Uniwersytet Muzyczny Fryderyka Chopina, Zachodniopomorski Uniwersytet Technologiczny w Szczecinie, Uniwersytet Rzeszowski, Pomorski Uniwersytet Medyczny, Uniwersytet Wrocławski, Uniwersytet Artystyczny w Poznaniu.

${ }^{13}$ Ustawa z 29 marca 1926 r. o prawie autorskim, t.jedn.: Dz. U. 1935, Nr 36, poz. 260.

${ }_{14}$ S. Ritterman, Komentarz do ustawy o prawie autorskim, Kraków 1937, s. 7.

${ }_{15}$ Ibidem, s. 9.

${ }^{16}$ Ustawa z 10 lipca 1952 r. o prawie autorskim, Dz. U. Nr 34, poz. 234 ze zm.

17 A. Kopff, Dzieło sztuk plastycznych $i$ jego twórca w świetle przepisów prawa autorskiego, Zeszyty Naukowe Uniwersytetu Jagiellońskiego. Rozprawy i Studia, t. 36, Kraków 1961, s. 10.

18 Ibidem. 
rają postać jednoznacznych zespołów, logicznie uporządkowanych sądów i pojęć kierowanych do umysłu odbiorcy ${ }^{19}$. Tak więc według Kopffa treść utworu naukowego jest odbiciem obiektywnie istniejącej rzeczywistości i dlatego nie może podlegać ochronie prawa autorskiego ${ }^{20}$.

Jan Błeszyński, komentując krytycznie stanowisko Andrzeja Kopffa, uznał za nieuzasadnione sprowadzenie pojęcia „utwór naukowy” jedynie do dzieł, które ustalają odkrycia lub prawdy naukowe ${ }^{21}$, ponieważ nie wydaje się zasadne postawienie znaku równości pomiędzy treścią dzieła naukowego a obiektywnie istniejacca rzeczywistością (ustaleniem naukowym). Od dzieła naukowego należy odróżnić to, z czym ono zapoznaje. Pojęcia dzieła naukowego nie można ograniczać jedynie do tych dziedzin, w obrębie których można posłużyć się pojęciem „odkrycie” - pomijając już nawet relatywność tego pojęcia, wynikająca zarówno z barier, które napotyka poznanie ze względu na wielopostaciowość zjawisk i procesów, ich złożoność, jak i ze względu na zmienność pojęcia nauki i kryterium naukowości w różnych okresach historycznych. Zdaniem Błeszyńskiego wyróżnianie dzieł naukowych może być przydatne jedynie ze względu na pełnione przez nie funkcje społeczne ${ }^{22}$.

Zdaniem Ryszarda Markiewicza w przypadku utworów naukowych podstawową rolą komunikatu jest funkcja przedstawiająca, odnosząca się do rzeczywistości empirycznej (referencyjnej), przy czym ze względu na to, że chodzi o poznanie naukowe, celem komunikatu jest maksymalnie dokładne przedstawienie tej rzeczywistości ${ }^{23}$. Warunkiem uznania utworu za naukowy jest spełnienie kryteriów naukowości z zakresu tematyki i metody uzyskiwania rezultatów oraz „nowość i oryginalność utworu, oceniona z punktu widzenia stanu wiedzy środowiska naukowego" ${ }^{24}$. Autor podkreśla, że przy kwalifikacji utworu naukowego uzasadnione jest „odnajdywanie jego twórczego charakteru w takich cechach charakterystycznych dla dzieł naukowych, jak np. sposób prowadzenia wywodu, dobór argumentów i przykładów”25. Ryszard Markiewicz, odnosząc się do szeroko rozpowszechnionej definicji utworu naukowego autorstwa Helmuta Haberstumpfa, stwierdza, że definicja ta obejmuje swym zakresem także wytwory tradycyjnie uznawane za nienaukowe: literaturę czysto techniczna, informacyjna, teksty popularyzatorskie ${ }^{26}$.

Już na tle obowiazywania ustawy o pr.aut. z 1994 r. Bogdan Michalski twierdził, że wyróżnikiem utworów naukowych jest cel poznawczy ${ }^{27}$. Z kolei

\footnotetext{
${ }^{19}$ Ibidem, s. 12.

${ }^{20}$ Ibidem, s. 15; A. Kopff, Wptyw postepu techniki na prawo autorskie, Zeszyty Naukowe Uniwersytetu Jagiellońskiego. Prace z Wynalazczości i Ochrony Własności Intelektualnej, z. 48, Kraków 1988, s. 26.

21 J. Błeszyński, Prawo autorskie, Warszawa 1988, s. 47-48.

${ }^{22}$ Ibidem, s. 48.

${ }^{23}$ Zob. R. Markiewicz, Dzieto literackie i jego twórca w polskim prawie autorskim, Kraków 1984, s. 9 i n.

${ }^{24}$ Idem, Ochrona prac naukowych, Zeszyty Naukowe Uniwersytetu Jagiellońskiego. Prace z Wynalazczości i Ochrony Własności Intelektualnej, z. 55, Kraków 1990, s. 17, 21 i 31.

${ }^{25}$ Ibidem, s. 20.

${ }^{26}$ Ibidem, s. 19.

${ }^{27}$ B. Michalski, Chronione elementy utworu naukowego, w: A. Adamczak (red.), Zbiór referatów z seminarium rzeczników patentowych szkót wyższych, Cedzyna 27 września - 1 października
} 
według Alicji Kędzierskiej-Cieślak w treści pracy naukowej mieści się teza lub rozwiązanie naukowe określonego problemu ${ }^{28}$. Natomiast Dariusz Czajka przyjmuje, że utwór naukowy w rozumieniu art. 1 pr.aut. winien posiadać następujące cechy:

1) wyjaśnienia naukowca są odbiciem osobistych doświadczeń twórcy lub obejmują wywód psychologiczny oparty na wyobraźni (intuicji) autora,

2) autor przedstawia opis przebiegu twórczego, który może cechować element indywidualizmu w zakresie doboru argumentów bądź ich układu strukturalnego, który ma twórczy charakter, tudzież proces ten zwieńczony jest odkryciem nowych faktów, ich związków, nowatorskiej ich interpretacji,

3) dobór faktów i rozumowania powinien być dokonany na podstawie indywidualnej oceny autora i podyktowany jego wyobraźnią oraz intuicja,

4) proponowana metoda czy też paradygmat naukowy ma charakter twórczy, jeżeli wybór przyjętych w niej kryteriów lub sposobów postępowania nie jest w sposób oczywisty przesądzony celami tej metody ${ }^{29}$.

Biorąc pod uwagę przedstawione poglądy, można zauważyć, że w doktrynie nie ogranicza się pojęcia utworu naukowego wyłącznie do utworu wyrażonego w określonej formie, np. utworu piśmienniczego. Zatem jeśli dany wytwór intelektualny, wyczerpujac przesłanki utworu określone w art. 1 ust. 1 pr.aut., cechuje się jednocześnie przymiotami wskazanymi w doktrynie, można uznać go za utwór naukowy, niezależnie od jego formalnego ujęcia.

\section{POGLĄDY JUDYKATURY NA TEMAT UTWORU NAUKOWEGO}

Utwory naukowe niezbyt często stanowią przedmiot postępowań sądowych, pomimo to na przestrzeni obowiązywania ustawy z 1952 r. i obecnie obowiązującej z 1994 r. można wskazać na kilka stanowisk judykatury w tym zakresie.

Przede wszystkim nadal zachowuje aktualność wyrok Sądu Najwyższego z 29 grudnia 1971 r., zgodnie z którym prawo autorskie nie różnicuje ochrony utworów w dziedzinie piśmiennictwa w zależności od naukowego bądź innego charakteru dzieła ${ }^{30}$. Jednakże w wyroku z 22 marca 1973 r. Sąd Najwyższy uznał, że w utworach naukowych jawna zbieżność stylu i treści fragmentów porównywanych publikacji nie może być uznana za przypadkowa, zwłaszcza gdy chodzi o definicje naukowe ${ }^{31}$. Wydaje się, że uogólnienie przyjęte przez Sąd, opierające się właściwie na przesłankach stylistycznych, może być zbyt daleko idące w skutkach. Może bowiem okazać się w przypadku pracy na-

\footnotetext{
1994 r., Wynalazczość i Ochrona Własności Intelektualnej, Biuletyn nr 10, Politechnika Kielce, Kielce 1994, s. 85.

28 A. Kędzierska-Cieślak, Pierwszeństwo instytucji naukowej do opublikowania utworu jej pracownika, „Państwo i Prawo” 51, 1996, z. 8-9, s. 81.

29 D. Czajka, Ochrona praw twórców i producentów. Prawo autorskie i prawa pokrewne, Warszawa 2010, s. 75-76.

${ }^{30}$ Wyrok SN z 29 grudnia 1971 r., I CR 191/71, „Orzecznictwo Sądu Najwyższego Izba Cywilna oraz Izba Pracy i Ubezpieczeń Społecznych” 1972, nr 7-8, poz. 133.

31 Wyrok SN z 22 marca 1973 r., I CR 3/73, niepubl.
} 
ukowej, że oryginalny rezultat twórczy autora pracy zostanie przesłonięty słusznymi skądinąd - argumentami przemawiajacymi na jego niekorzyść, a opierającymi się jedynie na zbieżności brzmień, i to być może o charakterze nietrafnym i drugorzędnym. Stąd też stosowanie w dalszym orzecznictwie analogii do przytoczonego wyroku powinno być bardzo wyważone.

Odnosząc się do treści utworu naukowego, w wyroku z 20 września 1976 r. Sąd Najwyższy uznał, że dzieło naukowe znamionuje element nowości, co pozwala odróżnić je od literatury „fachowej, technicznej, gospodarczej” ${ }^{2}$. Natomiast w wyroku z 24 listopada 1978 r. Sąd Najwyższy staną na stanowisku, że prawo autorskie nie jest powołane do rozstrzygania sporów naukowych i oceny wartości osiąnięć poszczególnych osób. Nie jest istotna funkcja prawdziwościowa. Natomiast ważna jest swoistego rodzaju kompozycja metodologiczna zawierająca nie tylko jeden z elementów, takich jak rysunek, tj. zapis graficzny wyrażajacy określoną tezę np. z zakresu nauk ścisłych, który nie ma autonomicznego i samoistnego znaczenia, tj. winien towarzyszyć mu opis weryfikacyjny określający kryteria, jak i opis procesu, który doprowadził do tego końcowego wyniku. Idea naukowa zawarta w dziele nie podlega ochronie autorskoprawnej, należy jedynie do tzw. elementów wolnych utworu. Chroniona jest natomiast pełna forma wyrazu, tj. materializacja tej idei w procesie weryfikacyjno-falsyfikacyjnym ${ }^{33}$.

Wyrok Sądu Najwyższego z 30 czerwca 2005 r. zalicza dzieła naukowe do tzw. utworów „niefikcjonalnych” (wraz z dziełami będącymi rezultatem działalności technicznej i tzw. drobnymi przedmiotami pr.aut.). W przypadku utworów „niefikcjonalnych” spełnienie przesłanki niepowtarzalności może być kwestionowane. Sąd stwierdził, że „wątpliwości co do twórczego i indywidualnego charakteru wymienionych dzieł wynikają z tego, że dotyczą one obiektywnie istniejącego (a więc nie »tworzonego«) stanu rzeczy, przedmiot i temat pracy sa z góry ustalone, metody badawcze z reguły sa znane i takie same, nieuniknione jest oparcie się na wcześniejszym dorobku". Dlatego kwestia, czy w konkretnym przypadku zaistniał margines swobody ujęcia tematu i czy twórca z tej swobody skorzystał, staje się kluczowa dla stwierdzenia, że badane dzieło jest utworem chronionym prawem autorskim. Zdaniem Sąu „przyznanie takiej ochrony uzależnione jest od stwierdzenia specyficznych, będących wynikiem indywidualnej kreacji autora, elementów wyrażajacych się $\mathrm{w}$ sposobie doboru i prezentacji danych oraz ich interpretacji, a także w formie osobistego i swobodnego (w pewnym zakresie) ich ujęcia" ${ }^{34}$.

Z wyroku Sądu Najwyższego z 8 września 1976 r. ${ }^{35}$ wynika, że do zaistnienia współtwórczości w sferze naukowej nie jest konieczne działanie twórców w takich samych płaszczyznach oddziaływania na efekt ostateczny dzieła. Otóż wkład twórczy profesora wyższej uczelni przy opracowywaniu wspólnie

${ }^{32}$ I CR 261/76, Lex, nr 63887.

${ }^{33}$ I CR 185/78, niepubl.

34 IV CK 763/04, „Orzecznictwo Sądu Najwyższego Izba Cywilna” 2006, nr 5, poz. 92.

35 IV CR 329/76, „Orzecznictwo Sądu Najwyższego Izba Cywilna oraz Izba Pracy i Ubezpieczeń Społecznych” 1977, nr 9, poz. 165. 
z adiunktem tejże uczelni skryptu, służącego do nauki przedmiotu wykładanego przez tego profesora, może polegać na różnorodnym działaniu:

- wspólnym pisaniu skryptu,

- wykorzystaniu przez adiunkta notatek z wykładów, będących owocem pracy naukowej profesora,

- opracowaniu skryptu przez adiunkta w porozumieniu z profesorem, na podstawie wyników badań naukowych i koncepcji, będących owocem pracy naukowej profesora oraz według jego wskazówek co do układu i treści.

Do utworu naukowego w działalności uczelni wyższej odnosi się wyrok Sądu Najwyższego z 3 października 2013 r., zgodnie z którym istotą wykładu (utworu naukowego) jako dzieła autorskiego jest jego treść zawierająca przekaz określonej myśli intelektualnej twórcy, której granice wytycza z góry zamówiony temat ${ }^{36}$. Również na pytanie Sąu Apelacyjnego w Rzeszowie z 14 października 2011 r. Sąd Najwyższy, rozpatrując zagadnienie prawne w uchwale z 14 lutego 2012 r., stwierdził, że utwór naukowy będący wynikiem działalności naukowo-dydaktycznej prowadzonej na wyższej uczelni może być uznany za utwór w rozumieniu przepisów prawa autorskiego. Utworem takim może być np. wykład akademicki ustanowiony z chwila jego zapisania czy wygłoszenia ${ }^{37}$.

\section{DEFINICJA UTWORU NAUKOWEGO}

Obecnie w literaturze prawniczej najbardziej rozpowszechniona jest definicja dzieła naukowego sformułowana przez Haberstumpfa: utwór, którego podstawowa funkcja komunikacyjna ma cel informacyjny, utwór taki nie jest zatem zorientowany na siebie, lecz na przedstawiony w nim, obiektywnie istniejący, stan rzeczy ${ }^{38}$. Uwzględniając ten pogląd, Janusz Barta i Ryszard Markiewicz posługują się następującą definicją utworów naukowych: utwory, które stanowią rezultat naukowego procesu poznawczego i które równocześnie, w swej podstawowej funkcji komunikacyjnej, są zorientowane nie „na siebie”, jak utwory artystyczne, lecz na przedstawienie obiektywnie istniejącej rzeczywistości ${ }^{39}$. Tak więc obiektywnie istniejące zjawiska nie są w swej istocie „stwarzane” przez twórcę, lecz jedynie przedstawiane.

Zdaniem Romana Ingardena dzieła naukowe służą przede wszystkim poznaniu lub odkryciu pewnej obiektywnie istniejącej rzeczywistości lub praw nią rządzących. Powstanie swe zawdzięczają zamierzeniom i czynnościom poznawczym autora, który wynik tych ustaleń stara się przekazać odbiorcom w sposób jednoznaczny, niebudzący wątpliwości co do intencji wykładu. Zadaniem natomiast dzieła artystycznego nie jest zaznajamianie odbiorcy z obiek-

${ }^{36}$ II UK 103/13, Legalis, nr 924645.

${ }^{37}$ III UZP 4/11, Lex, nr 1108381.

${ }^{38}$ H. Haberstumpf, Zur Individualität wissenschaftlicher Sprachwerke, Freiburg 1982, s. 2226 (za: R. Markiewicz, Ochrona prac..., s. 19).

${ }^{39}$ Zob. J. Barta, R. Markiewicz, w: iidem (red.), Prawo autorskie i prawa pokrewne, Warszawa 2011, s. 156. 
tywnie istniejąca rzeczywistością (przynajmniej nie jest to celem głównym pracy artystycznej), ale oddziaływanie na sferę uczuć z zamiarem wywołania u niego przeżyć estetycznych ${ }^{40}$. Według Ingardena do istoty utworu naukowego „należy to, że ma ustalać i zawierać wyniki poznania naukowego w jakiejś dziedzinie, i przekazywać je innym tak, aby jego czytelnicy mogli dalej prowadzić i rozwijać te badania naukowe" ${ }^{41}$.

Jak stwierdza Andrzej Chobot, utwór ma charakter naukowy, gdy jest „rezultatem twórczej pracy badawczej”“2. Według Marii Poźniak-Niedzielskiej i Grzegorza Tylca „naukowy” charakter utworu oznacza, że chodzi tu o spełniajace ponadto przesłanki z art. 1 ust. 1 pr.aut. rezultaty działalności badawczej, które „w wyniku procesu poznawczego umożliwiają przedstawienie wycinka istniejącej rzeczywistości, ustalenia przyczyn i skutków zjawisk przyrodniczych i społecznych" ${ }^{43}$. Uzupełniając tę wypowiedź, Tylec dodaje, że utwór naukowy stanowi rezultat działalności badawczej, który w wyniku procesu poznawczego umożliwia przedstawienie wycinka istniejącej rzeczywistości, ustalenie przyczyn i skutków zjawisk przyrodniczych i społecznych, stanowi rezultat naukowego procesu poznawczego i w swej podstawowej funkcji komunikacyjnej nie jest zorientowany „na siebie”, jak utwór artystyczny, lecz na przedstawienie obiektywnie istniejaccej rzeczywistości ${ }^{44}$.

W opinii Adriana Niewęgłowskiego termin „utwór naukowy” jest pojęciem szerszym od wyniku prac badawczych, gdyż oprócz niego obejmuje także inne składniki, takie jak np. argumentacja czy rozumowanie twórcy. Wynik prac badawczych i utwór naukowy stanowią dobra intelektualne odrębne, chociaż pozostające w stosunku krzyżowania. Utwór naukowy nie musi zawierać rozwiązania naukowego, zatem nie musi być zupełny (art. 1 ust. 3 pr.aut.) ${ }^{45}$. Niewęgłowski definiuje utwór naukowy jako każde dzieło z „zawartościa naukową", czyli przejawiające intencję przedstawienia, porównania, analizy, hipotez lub wyników badań naukowych. Utwór naukowy powinien wskazywać intencję poszerzenia zasobu wiedzy naukowej przez autora, ale nie można wymagać, by ten zasób faktycznie poszerzał; wszelkie utwory, również naukowe, sa chronione niezależnie m.in. od ich wartości, dlatego nie można także ochrony utworu naukowego uzależniać od jego określonej wartości. Trudno też twierdzić, że musi zawsze przedstawiać wyniki badań, a nie np. hipotezy, skoro jest chroniony także wtedy, gdy nie jest ukończony ${ }^{46}$.

Odmienny pogląd od powyższego zdaje się prezentować Piotr Stec, sugerując, że intencją ustawodawcy było ograniczenie tego pojęcia do utworów nauko-

40 Zob. R. Ingarden, O sztuce ttumaczenia, Wrocław 1955, s. 133.

41 Idem, O poznawaniu dzieła literackiego, Warszawa 1976, s. 143.

42 A. Chobot, Regulacja prawna twórczej pracy badawczej w stosunkach pracy, Warszawa 1975 , s. 162

${ }^{43}$ M. Poźniak-Niedzielska, G. Tylec, Działalność naukowo-dydaktyczna na wyższej uczelni $w$ świetle prawa autorskiego, „Państwo i Prawo” 64, 2009, z. 5, s. 34.

${ }^{44}$ G. Tylec, Z problematyki ochrony prawnoautorskiej dzieła naukowego, „Przegląd Prawno-Ekonomiczny" 2009, z. 2(7), s. 28.

${ }^{45}$ A. Niewęłowski, Wyniki prac badawczych $w$ obrocie cywilnoprawnym, Warszawa 2010, s. 177 .

${ }^{46}$ Idem, Wybrane zagadnienia współautorstwa $w$ pracach naukowych, „Ius Novum” 2010, nr 2, s. 175 . 
wych sensu proprio, tj. będących opracowaniem rezultatów pracy badawczej ${ }^{47}$. Z kolei Andrzej Szewc uważa, że w świetle poglądów doktryny prawa autorskiego podstawowym warunkiem uznania określonych dzieł intelektualnych za utwory naukowe jest to, że: a) spełniaja kryterium naukowości w zakresie tematyki i metody uzyskiwania rezultatów, b) odpowiadają wymogom nowości i nieoczywistości (oryginalności) ocenianym z punktu widzenia stanu wiedzy środowiska naukowego ${ }^{48}$.

Nieco z innej strony podchodzący do problematyki utworów naukowych Adam T. Troskolański w 1978 r. stwierdził, że dziełem naukowym nazywamy utwór piśmienniczy, obejmujący zakresem treści wyniki działalności twórczej $\mathrm{w}$ dowolnej dziedzinie nauki, ujęte w sposób fragmentaryczny lub kompletny, zależnie od tego, czy dotyczy jednego zagadnienia, czy też kompleksu zagadnień tworzących odrębna dyscyplinę naukowa ${ }^{49}$. Również pochodzący z $1961 \mathrm{r}$. Kodeks dobrych obyczajów w publikacjach naukowych ${ }^{50} \mathrm{w}$ pkt II.4. zaliczał do kategorii „oryginalnych prac naukowych” tekst zredagowany w taki sposób, aby odpowiednio wykwalifikowany badacz naukowy, wyspecjalizowany w tej samej gałęzi wiedzy, mógł posługując się wskazaniami tekstu i tylko nimi:

- bądź powtórzyć doświadczenia i uzyskać wyniki opisane w tekście z ewentualnymi błędami w granicach lub poniżej granic wyznaczonych przez autora,

- bądź powtórzyć spostrzeżenia i ocenić wnioski autora,

- bądź skontrolować dokładność wyników analiz i rozważań, które doprowadziły autora do jego wniosków ${ }^{51}$.

Ostatnie z przytoczonych poglądów zachowują aktualność o tyle, o ile zamiast „tekstu” brana pod uwagę będzie dowolna postać wyrazu uzyskana w drodze naukowej działalności badawczej.

\section{POSTACIE UTWORÓW NAUKOWYCH}

W dotychczasowym dorobku doktryny czy judykatury prawa autorskiego nie pojawił się żaden - nawet otwarty - katalog utworów uznawanych za naukowe. Stworzenie tego rodzaju „wykazu” wymaga zgromadzenia poglądów, formułowanych na użytek analizy danego przypadku utworu:

${ }^{47}$ P. Stec, Uczelnia jako podmiot praw na dobrach niematerialnych, „Państwo i Prawo” 63, 2008, z. 1, s. 50.

${ }^{48}$ A. Szewc, Dzieła naukowe i ich status w prawie autorskim, „Państwo i Prawo” 52, 1997, z. 10, s. 25 .

${ }^{49}$ A. T. Troskolański, O twórczości. Piśmiennictwo naukowo-techniczne, Warszawa 1978, s. 401

${ }^{50}$ A Code of good practice for scientific publications z 16 czerwca 1962 r., opracowany przez Komitet porozumiewawczy oganizacji: FID - Fédération Internationale de Documentation, ICSU International Council of Scientific Unions, IFLA - International Federation of Library Association, ISO - International Organization for Standarization, UNESCO - United Nations Educational, Scientific and Cultural Organization (http://unesdoc.unesco.org/images/0012/001267/126727eb.pdf).

${ }^{51}$ Tłumaczenie za: A. T. Troskolański, op. cit., s. 456-457. 
1) Ryszard Markiewicz wyraźnie zaliczył słowniki do prac naukowych, zreszta przy okazji postulatu objęcia ich prawami „sasiednimi”, wraz z mapami, planami i rysunkami technicznymi, fotografiami, zestawieniami danych, bibliografiami, katalogami, opracowaniami naukowymi utworów lub innych tekstów, programami dla maszyn cyfrowych. Autor definiuje prawa „sasiednie" jako zbiorczą nazwę dla różnych praw podmiotowych wyłącznych, których przedmiot nie spełnia wprawdzie autorskoprawnej przesłanki twórczości, ale bądź jest zbliżony do przedmiotu prawa autorskiego, bądź jego eksploatacja związana jest z koniecznym wykorzystaniem utworu. Należy podkreślić, że uwagi te przedstawione były na gruncie ustawy o prawie autorskim z $1952 \mathrm{r}$., w której wyraźnie przewidziana była ochrona dla słowników jako dzieł zbiorowych ${ }^{52}$.

2) Według dotychczas najobszerniejszego słownika języka polskiego encyklopedia to wydawnictwo naukowe, będące systematycznym zbiorem (ułożonym alfabetycznie lub według zagadnień) wiadomości ze wszystkich dziedzin wiedzy albo z jednej gałęzi wiedzy ${ }^{53}$. Rzeczywiście należy się zgodzić, że w przypadku encyklopedii (lub słownika) mamy do czynienia wyłącznie z selektywnym, wybiórczym i skondensowanym przedstawieniem obiektywnie istniejącej rzeczywistości, i to w zakresie odwzorowujacym, systematyzującym, poznawczym, w mniejszym zaś stopniu reprezentującym własne stanowisko autorów poszczególnych wkładów do utworu zbiorowego ${ }^{54}$.

3) Beata Gadek-Giesen uznaje, że pojęcie „dzieło naukowe” jest terminem zbiorczym, obejmującym swoim zakresem bardzo różne kategorie utworów. Rozpiętość jest olbrzymia. W zbiorze tym znalazłyby się bowiem zarówno prace typowo badawcze o charakterze wybitnie naukowym, jak i prace egzaminacyjne, prace magisterskie, zbiory pytań, pisma procesowe, testy itp..$^{55}$

4) Zdaniem Andrzeja Chobota może być uznany za utwór naukowy podręcznik do nauczania na najwyższym poziomie ${ }^{56}$. Opracowanie podręczników uniwersyteckich może być uznane za twórczą pracę badawcza, gdy stanowia one oryginalne syntetyczne ujęcia, dające równocześnie krytyczny przegląd osiagnięć danej dyscypliny oraz problemów spornych bądź jeszcze nie zbadanych ${ }^{57}$. Specyficznymi odmianami prawnymi twórczej pracy badawczej są prace: projektowa, konstrukcyjna i technologiczna (najczęściej mówi się o tego typu pracach jako o twórczości wynalazczej) ${ }^{58}$. Twórczą pracą badawczą może być praca projektowa, np. projekt architektoniczny, utwór kinematograficzny (np. film o życiu nie znanego dotąd gatunku zwierząt $)^{59}$. Nie jest wykluczone,

${ }^{52}$ Zob. R. Markiewicz, Ochrona prac..., s. 64.

${ }^{53}$ Stownik języka polskiego, red. W. Doroszewski, Warszawa 1960.

${ }^{54}$ D. Sokołowska, Utwory zbiorowe w prawie autorskim ze szczególnym uwzględnieniem encyklopedii i stowników, Zeszyty Naukowe Uniwersytetu Jagiellońskiego. Prace z Wynalazczości i Ochrony Własności Intelektualnej, z. 76, Kraków 2001, s. 127.

${ }_{55}$ B. Gadek-Giesen, Plagiat dziet naukowych - zagadnienia wybrane, „Zeszyty Naukowe Uniwersytetu Jagiellońskiego. Prace z Prawa Własności Intelektualnej” 2011, z. 112, s. 78.

${ }^{56}$ A. Chobot, op. cit., s. 170.

57 Ibidem, s. 50.

${ }^{58}$ Ibidem.

${ }^{59}$ Ibidem, s. 174. 
że utwór fotograficzny może być naukowy, najczęściej jednak fotografia naukowa będzie materiałem do utworu naukowego w niektórych dziedzinach (np. sporządzenie mapy nieba, badanie galaktyk - jest podstawowym narzędziem badawczym $)^{60}$.

5) Krzysztof Gienas twierdzi, że wyniki niektórych prac naukowych przybierają jednocześnie postać innej kategorii utworów. Ma to miejsce w przypadku badań informatycznych prowadzacych niejednokrotnie do powstania oprogramowania komputerowego ${ }^{61}$.

6) Zdaniem Janusza Barty i Ryszarda Markiewicza utworami naukowymi (w rozumieniu art. 14 pr.aut.) mogą być także takie utwory o cechach poznawczych, które mają postać fotografii (zwłaszcza gdy towarzyszy jej tekst), rysunku technicznego, projektu plastycznego (np. modele czy rekonstrukcje osad, czy zwierząt prehistorycznych), a nawet postać projektu architektonicznego (o szczególnych, stanowiących wynik badań naukowych własnościach wytrzymałościowych $)^{62}$.

7) Według Andrzeja Szewca naukowa zawartość utworu może być wyrażona jako np. fotografia naukowa czy animowany film naukowy ${ }^{63}$.

8) Aurelia Nowicka uważa, że mimo iż w kategorii określonej w art. 1 ust. 2 pkt 1 pr.aut. utwory naukowe zostały wymienione obok programów komputerowych, nie wyklucza to uznania, że utworem naukowym może być również program komputerowy ${ }^{64}$.

9) Maria Poźniak-Niedzielska i Grzegorz Tylec twierdza, że wykład akademicki, który ma mieć cechy dzieła naukowego, z reguły odznacza się pewnym uporządkowaniem i przemyślanym wcześniej układem prezentowanych treści. Immanentną cechą wykładu akademickiego nie jest sposób prezentacji, ale jego treśćc ${ }^{55}$.

10) Jakub M. Doliński jest zdania, że w rozumieniu prawa autorskiego testy psychologiczne można chronić jako utwór naukowy, choć orzecznictwo sądowe wskazuje na ich ochronę jako dokumentu urzędowego ${ }^{66}$. Sama teoria naukowa sensu stricto nie może być przedmiotem ochrony autorskoprawnej, w odróżnieniu od kreatywnego sposobu wyrażenia, jakim jest test psychologiczny. Można zakładać, że testy psychologiczne posiadają charakter przedmiotu prawa autorskiego jako utwór naukowy. Przeprowadzenie właściwej diagnozy na podstawie testów psychologicznych uzależnione jest od poprawnej interpretacji ich wyników w oparciu o przygotowane klucze/normy powstałe zgodnie z wyznaczonymi standardami ${ }^{67}$. Zdaniem Jerzego Brzezińskiego test

\footnotetext{
${ }^{60}$ Ibidem, s. 175 .

${ }^{61} \mathrm{~K}$. Gienas, Jak prawo autorskie chroni prace naukowe, „Rzeczpospolita” z 23 czerwca 2008 r., s. C-008.

62 J. Barta, R. Markiewicz, w: iidem (red.), op. cit., s. 156.

${ }^{63}$ A. Szewc, op. cit., s. 27.

64 A. Nowicka, Uprawnienia instytucji naukowych, w: System prawa prywatnego, t. 13: Prawo autorskie, red. J. Barta, Warszawa 2013, s. 114.

${ }^{65}$ M. Poźniak-Niedzielska, G. Tylec, op. cit., s. 37.

66 J. M. Doliński, Testy psychologiczne $w$ prawie własności intelektualnej, „Monitor Prawniczy" 2013, nr 10, s. 533. Ocena wydaje się nietrafna z uwagi na powołanie się na wyrok SN z 26 września 2001 r. (IV CKN 458/00), dotyczący pytań testowych stosowanych przy egzaminach na prawo jazdy.

67 J. M. Doliński, op. cit., s. 528.
} 
psychologiczny ma stanowić operacjonalizację teorii psychologicznej, będącej empirycznie potwierdzoną teorią naukowa ${ }^{68}$.

11) Rafał Golat wskazuje, że w zakresie działalności pracowników naukowo-dydaktycznych wyższych uczelni przedmiot prawa autorskiego będa stanowić w szczególności: a) wykłady akademickie, b) rozprawy naukowe, popularnonaukowe, podręczniki, skrypty, c) artykuły, recenzje prac oraz projektów prac naukowo-badawczych, recenzje dorobku naukowego, d) indywidualny sposób przedstawienia odkryć lub badań naukowych (samoistnie ujmowane odkrycia naukowe nie podlegają bezpośredniej ochronie prawnoautorskiej), ponieważ warstwa tekstu - określana jako forma dzieła - ma z reguły w pracach naukowych charakter twórczy ${ }^{69}$.

12) Maria Poźniak-Niedzielska i Grzegorz Tylec opowiadaja się za poglądem, że utwór stworzony w celu realizacji procesu dydaktycznego na wyższej uczelni (np. wykład, skrypt, podręcznik) może być uznany za utwór naukowy ${ }^{70}$.

13) Według Agnieszki Górnicz-Mulcahy utworami naukowymi (w rozumieniu art. 14 pr.aut.) mogą być też utwory o cechach poznawczych (np. fotografia, rysunek plastyczny) ${ }^{71}$.

14) Ewa Ferenc-Szydełko uważa, że dzieła naukowe mogą być też formami plastycznymi, takimi jak modele, makiety. Można je wyrażać także fotografią, niewykluczona jest forma choćby częściowo stworzona z dźwięków, a także forma wideogramowa, animacja komputerowa i in. ${ }^{72}$

15) Zdaniem Ryszarda Markiewicza utworami naukowymi moga być takie plastyczne środki przedstawieniowe, jak rysunki, mapy, tabele, formularze, wykresy, fotografie, przedmioty trójwymiarowe ${ }^{73}$.

16) Piotr Stec uważa, że utwory dydaktyczne mogą być utworami nauko$\mathrm{wymi}^{74}$.

17) Wyrok Sądu Najwyższego z 24 listopada 1978 r. - przykładem utworu naukowego jest np. rysunek wyrażajacy określoną tezę z zakresu nauk ścisłych (np. chemii czy fizyki) ${ }^{75}$.

18) Uchwała Sądu Najwyższego z 14 lutego 2012 r. - wykład o charakterze niestandardowym, niepowtarzalnym, spełniajaccym kryteria twórczego i indywidualnego utworu naukowego, jest przedmiotem prawa autorskiego. Sąd Najwyższy stwierdził, że utwór naukowy będący wynikiem działalności naukowo-dydaktycznej prowadzonej na wyższej uczelni może być uznany za

\footnotetext{
68 J. Brzeziński, Metodologia badań psychologicznych, Warszawa 2003, s. 167.

${ }^{69}$ R. Golat, Komentarz do ustawy o prawie autorskim i prawach pokrewnych z uwzględnieniem ostatnio uchwalonych i proponowanych zmian, Jaktorów 2002, s. 30.

${ }^{70}$ M. Poźniak-Niedzielska, G. Tylec, op. cit., s. 36.

71 A. Górnicz-Mulcahy, Utwór naukowy jako przedmiot ochrony autorskoprawnej, w: E. Marszałkowska-Krześ (red.), Aktualne zagadnienia prawa prywatnego, Wrocław 2012, s. 45-46.

${ }^{72}$ E. Ferenc-Szydełko, w: eadem (red.), Ustawa o prawie autorskim i prawach pokrewnych, Warszawa 2014, s. 33.

73 R. Markiewicz, Ochrona prac..., s. 43.

${ }^{74}$ P. Stec, op. cit., s. 51. Za wyłączeniem ich spod pojęcia utworów naukowych opowiadają się J. Błeszyński (zob. J. Błeszyński, M. Staszków, Prawo autorskie i wynalazcze, Warszawa 1983, s. 103) i A. Chobot (idem, op. cit., s. 170).

${ }^{75}$ I CR 185/78, niepubl.
} 
utwór w rozumieniu przepisów prawa autorskiego. Utworem takim może być np. wykład akademicki ustanowiony z chwila jego zapisania czy wygłoszenia ${ }^{76}$.

19) Wyrok Sądu Najwyższego z 3 października 2013 r. - istotą wykładu (utworu naukowego) jako dzieła autorskiego jest jego treść zawierająca przekaz określonej myśli intelektualnej twórcy, której granice wytycza z góry zamówiony temat ${ }^{77}$.

20) Pismo z 8 sierpnia 2012 r. Izby Skarbowej w Warszawie - może być utworem naukowym utwór kartograficzny i program komputerowy, a także inne utwory wymienione w art. 1 ust. 2 pr.aut. W przypadku np. specjalistycznego oprogramowania komputerowego (wykorzystywanego w automatyce, medycynie, fizyce kwantowej, biotechnologii) proces tworzenia tego oprogramowania może być związany z badaniami naukowymi, a w konsekwencji prowadzić do powstania dzieła (utworu) naukowego ${ }^{78}$.

Niezależnie od poglądów doktryny i orzecznictwa można brać pod uwagę przepisy stosowane w działalności jednostek naukowych w przypadku oceny osiagnięć naukowych. Treść § 6 ust. 1 rozporządzenia Ministra Nauki i Szkolnictwa Wyższego z 13 lipca 2012 r. w sprawie kryteriów i trybu przyznawania kategorii naukowej jednostkom naukowym ${ }^{79}$, dotyczącego oceny osiąnięć naukowych i twórczych jednostki naukowej, uzasadnia wzbogacenie katalogu utworów naukowych o następujące pozycje: monografie naukowe, edycje tekstów źródłowych, leksykografie, atlasy i mapy wieloaspektowe, tłumaczenia publikacji zagranicznych, tematyczne encyklopedie i leksykony, komentarze do ustaw, opracowania krytyczne tekstów literackich, słowniki biograficzne i bibliograficzne, bibliografie, katalogi zabytków. Z uwagi na pkt 5 załącznika nr 1 do rozporządzenia, rozważyć też można poszerzenie tego katalogu o następujace przykłady: utwór z zakresu architektury i urbanistyki lub sztuk projektowych, utwór muzyczny, dzieło plastyczne (monumentalne realizacje w przestrzeni publicznej, realizacje multimedialne, cykle prac plastycznych), dzieło konserwatorskie wraz z dokumentacja, projekt konserwatorski, film pełnometrażowy, film krótkometrażowy, film dokumentalny, spektakl teatralny, spektakl operowy, spektakl baletowy, rekonstrukcja zabytkowego instrumentu muzycznego, rekonstrukcja filmu lub nagrania dźwiękowego.

\section{PODSUMOWANIE}

Zważywszy na rozmaitość dyscyplin naukowych, w których moga pojawiać się utwory naukowe, uniwersalne ustalenie definicji utworu naukowego wymagałoby przeglądu stanowisk reprezentantów poszczególnych dyscyplin. Możliwe, że zbyt pochopne formułowanie szczegółowych wniosków w tym za-

${ }^{76}$ III UZP 4/11, Lex, nr 1108381. Zob. też wyroki SN z 4 czerwca 2014 r.: II UK 430/13 (Lex, nr 1480060), II UK 543/13 (Lex, nr 1495940), II UK 548/13 (Lex, nr 1496287).

77 II UK 103/13, Legalis, nr 924645. Zob. też wyroki SN z: 27 sierpnia 2013 r., II UK 26/13 (Lex, nr 1379926); 28 sierpnia 2014 r., II UK 12/14 (Lex, nr 1521243).

${ }^{78}$ IPPB5/423-371/12-5/PS, Lex, nr 158154.

79 T.jedn.: Dz. U. 2014, poz. 1126. 
kresie mogłoby doprowadzić do pominięcia aspektów determinujących twórczość naukową w którejkolwiek z dyscyplin naukowych. Z kolei poprzestanie na definicji zbyt ogólnej mogłoby być tożsame z akceptacją definicji pojawiającej się w regulaminach uczelni wyższych (,utwór zawierający rezultaty pracy naukowej").

Z powyższych względów kwestię definiowania utworu naukowego na gruncie przepisów prawa autorskiego nadal należy uważać za otwarta, pomimo prób podejmowanych w tym względzie w nauce i orzecznictwie. Wprawdzie trudno rekomendować definiowanie utworu naukowego w przepisach prawa, to jednak nadal można oczekiwać stosownego definiowania w regulaminach zarządzania prawami autorskimi i prawami pokrewnymi oraz prawami własności przemysłowej oraz zasad komercjalizacji w uczelniach wyższych, zwłaszcza że zgodnie z art. 46 pkt 1 ustawy z 11 lipca $2014 \mathrm{r} .{ }^{80}$ uczelnie wyższe maja obowiazek uchwalenia regulaminów zgodnych ze znowelizowanymi przepisami ustawy - Prawo o szkolnictwie wyższym do 1 kwietnia $2015 \mathrm{r} .{ }^{81}$ Należy podkreślić, że utwory naukowe moga powstawać we wszystkich dyscyplinach naukowych, przybierając postać adekwatną do obranej formy wyrażenia oraz stosowną do metody przeprowadzonych badań i możliwości przedstawienia uzyskanych wyników badawczych. W szczególności zaś należy odrzucić pogląd, że utwór naukowy może zostać wyrażony wyłącznie w formie piśmienniczej.

dr hab. Dorota Sokołowska

Uniwersytet im. Adama Mickiewicza w Poznaniu

THE CONCEPT AND FORM OF SCIENTIFIC WORK IN LIGHT OF COPYRIGHT LAW

Sum mary

The provisions of the Act on Copyright and Related Rights of 4 February 1999 do not provide any definition of scientific work but merely make a reference to it in Article 1 clause 2 point 1 , refer to it more broadly in Article 14, and also refer to it in Article 29 Copyright (citation). In the doctrine, an opinion that is worth mentioning is that of J. Barta and R. Markiewicz who claim that scientific works are the result of a scientific cognitive process and are, at the same time, in their basic function of communication, oriented not to 'themselves' as works of art, but focused on presenting the objective reality.

The issue of defining scientific work within the framework of copyright law is still open, regardless numerous attempts undertaken by scholars and judges to formulate its definition. Although it may not really be advisable to recommend that a legal definition of scientific work be provided, it seems reasonable to expect that a definition of such work is available in rules governing establishments of higher education.

It must be stressed, though, that scientific works may be produced in all kinds of scientific disciplines, and take the form that seems adequate and in line with the adopted method of research as well as with the capability of presenting research results. What is of particular importance though, is rejection of a view that scientific work may only take the form of a written paper or another paper form.

${ }^{80}$ Ustawa z 11 lipca 2014 r. o zmianie ustawy - Prawo o szkolnictwie wyższym oraz niektórych innych ustaw, Dz. U. 2014, poz. 1198.

${ }^{81} \mathrm{Tj}$. w terminie 6 miesięcy od dnia wejścia w życie ustawy z 11 lipca 2014 r., czyli 1 października $2014 \mathrm{r}$. 
